\title{
Posttraumatic Bacterial Infections in Extremities before and after Osteosynthesis in Small Animals
}

\author{
K. SOONTORNVIPART ${ }^{1}$, A. NEČAS ${ }^{1}$, M. DVOŘ́́K ${ }^{1}$, J. ZATLOUKAL ${ }^{1}$, J. SMOLA $^{2}$ \\ Department of Surgery, Orthopaedics and Radiology, Small Animal Clinic ${ }^{1}$, Department of Microbiology ${ }^{2}$, \\ Faculty of Veterinary Medicine, University of Veterinary and Pharmaceutical Sciences, Brno, Czech Republic
}

Received March 7, 2003

Accepted May 26, 2003

\begin{abstract}
Soontornvipart K., A. Nečas, M. Dvořák, J. Zatloukal, J. Smola: Posttraumatic Bacterial Infections in Extremities before and after Osteosynthesis in Small Animals. Acta Vet. Brno 2003, 72: 249-260.

Posttraumatic osteomyelitis is one of the most serious complications after fracture treatment. Even though first-generation cephalosporins are always recommended as the first choice of antibiotic prophylaxis in orthopaedic surgery, they cannot eradicate all bacteria, which can enter into the fractured bone during orthopaedic procedures.

The purpose of this study was to identify bacteria cultured from surgical wounds during osteosynthesis in order to select properly suitable antibiotic prophylaxis in our clinical practice. Our study was performed on 60 patients with long bone fractures operated at the Department of Surgery and Orthopaedics, Small Animal Clinic, University of Veterinary and Pharmaceutical Sciences, Brno. The patients without an antibiotic treatment 24 hours prior to surgery were included in the study. Samples for bacterial culture were collected before and after internal fixation of the fracture. Several factors possibly influencing the risk of infection were evaluated. Patients with severe degree of soft tissue damage and with open fractures were at higher risk of infection before osteosynthesis, whereas the patients younger than one year, with positive cultures before surgery, with plate and screw fixations, with primary bone healing, with abnormal radiographic findings and intramuscularly anesthetized patients were at a significantly higher risk of bacterial infection after the fracture fixation. A high percentage of the bacterial isolates was Pseudomonas aeruginosa resistent to cephalosporins. Although we use cephalosporins prophylactically in all patients undergoing orthopaedic surgery in our clinic, the incidence of postoperative infections was very low. Therefore, it is obvious that the use of cephalosporins as preoperative prophylaxis is sufficient in most cases. In the patients at high risk of osteomyelitis development (polytraumatized or immunosuppressed patients, patients receiving prosthetic joint or large metallic implants), or in the patients where the infection is already present, it is important to know hospital-specific pathogens to select adequate complementary antibiotics (in our case we use cephalosporines together with quinolones such as enrofloxain). This emphasizes the need of epidemiologic studies, specific for each clinic.
\end{abstract}

Osteomyelitis, bone, dog, cat, surgical attire, nosocomial infection

Posttraumatic osteomyelitis or osteitis is described as resulting from trauma or nosocomial infection during the treatment of trauma that allows pathogens to enter bone, proliferate in traumatized tissue and cause subsequent bone infection (Parker 1987; Ste in et al. 1998). Predisposing factors to osteomyelitis include bacterial contamination in combination with severe trauma, surgical intervention, the presence of dead bone, or metallic implants, especially if bone or implants are unstable (Gristina and Costerton 1989). Posttraumatic osteomyelitis is nearly always infectious in etiology, caused by various pathogens. The typical causative agents of this infection are aerobic bacteria especially staphylococcal species (Johnson 1994; Love and Johnson 1992; Stevenson et al. 1986). Even though staphylococci cause about 50-60\% of bone infections in dogs (J oh n s on 1994), many organisms such as pyogenic streptococci (Calza et al. 2001), gram-negative 
aerobic bacteria (eg. Escherichia coli, Pseudomonas spp., Proteus spp. and Klebsiella spp.) (Hirsch and Smith 1978), and coagulase-negative staphylococci (Allignet et al. 1999; Stein et al. 1998; Shuttleworth et al. 1997) are commonly found. Although aerobic bacteria are commonly responsible for these causative posttraumatic infections, some uncommon microorganisms such as Brucella canis (Smeak et al. 1987), Mycobacterium avium (Caywood et al. 1978) can be found. Furthermore, anaerobic bacteria such as Peptostreptococcus anaerobius, Propionibacterium spp., Actinomyces viscosus, Fusobacterium nucleatum, Bacteroides spp., Clostridium villosum were isolated. It is also reported that Wolinela recta, Leishmania donovani (Johnson 1994), Blastomyces dermatitidis (Marcellin-Little et al. 1996), Scedosporium prolificans (Sw erczek et al. 2001) can cause osteomyelitis in humans and domestic animals (Muir and John son 1992; Hodgin et al. 1992) but their incidences are rare.

According to the previous study (Dvořák et al. 2000), it was found that about $30 \%$ of $40 \%$ of the patients who had complications after osteosynthesis had abnormal radiological bone healing without any abnormal clinical signs. It was suspected that it might be caused by posttraumatic osteomyelitis or cryptic infection.

The purpose of this present study is to find out the type of aerobic bacteria, which plays an important role in the posttraumatic infection before and after fracture osteosynthesis. If the type of bacteria can be identified, the suitable antibiotic prophylaxis can be properly selected to achieve an effective prevention of posttraumatic osteomyelitis after osteosynthesis (Love and John s on 1992). Since poor aseptic and surgical techniques have been the primary cause of posttraumatic infection (Waldvogel and Vasey 1983), the aseptic techniques in orthopaedic surgery are also theoretically evaluated.

\section{Materials and Methods}

Our study was performed on 60 patients who had undergone osteosynthesis in extremities at the Department of Surgery and Orthopaedics, Small Animal Clinic, University of Veterinary and Pharmaceutical Sciences Brno from October 2001 till October 2002. All the patients were treated according to the principles of AO/ASIF with open reduction and internal fixation. The patients without antibiotic treatment 24 hours before surgery were included in our study. The methods of fracture repair were selected according to the fracture-patient assessment score (Piermattei and Flo 1997). The osteosynthesis procedures were performed by two experienced orthopaedists. Patients were hospitalized from 2-6 days in our clinic to receive standard postoperative care. They were returned to our clinic at 4-8 weeks after operation for follow-up orthopaedic and radiographic examinations. The next follow-ups were carried out at 4-6-week intervals, if needed. The implants for internal fracture were removed after clinical and radiological bone healing. Long bone diaphyseal fractures were classified using an Unger's system (Miller et al. 1998). In cases of physeal injury, the Salter-Harris (1963) classification was used. Fracture classifications were used for communications among surgeons and radiologists.

All data of the patients, including breed, age, sex, type of fracture (based on the classification system adopted by AO vet (Unger 1990)), methods of internal fixation, interval between the time of injury and surgery, type of bone healing, type of anaesthesia, radiographic finding, and type of surgical attire used in operation were recorded and evaluated.

Routine preoperative patient preparation and disinfectants used (Nečas et al. 2000b) were theoretically evaluated. Preoperative surgical site preparations were performed starting with hair clipping with an electric clipper, and then 3-5 min povidone-iodine scrubbing, and chlorhexidine spraying were applied to the preoperative operation site. All surgical instruments were sterilized with autoclave $\left(132-135^{\circ} \mathrm{C} ; 10-25 \mathrm{~min}\right)$. Povidone-iodine and alcohol were used for hand-scrubs of surgical team.

Two types of surgical attire were used in our present study ( 96 operations). There were: Foliodrape ${ }^{\circledR}$ (Hartmann) including disposable non-woven surgical gowns with incision drape which was performed in 28 operations.

Reusable woven (cotton) surgical gowns with disposable non-woven polypropylene drape (Polydrape ${ }^{\circledR}$ ) which were performed in 68 operations.

Foliodrape ${ }^{\circledR}$ were mainly selected in osteosynthetic procedures ( 21 operations) whereas reusable gowns with Polydrape ${ }^{\circledR}$ were always used when the implants were removed (58 operations). Types of surgical attire were also statistically analyzed for their influences on the risk of infection among several factors of patients.

Our study was divided into two parts; bacterial culture was performed before osteosynthesis and when the internal fixations were removed.

In the first part, 1 gram of tissue and/or bone fragment at the fracture site was collected. Furthermore, another sample was taken by means of sterile cotton sponge, which was saturated with blood. Both types of sample were collected from 55 patients when the fractured bone was approached to perform internal fixation. Samples were 
collected in Amies transport medium (CM 425, Oxoid) and or in modified Cary-Blair medium (CM 519, Oxoid). To perform bacterial cultivation, samples were inoculated onto Blood agar base (CM 854, Oxoid) and MacConkey's agar (CM 7b, Oxoid) and also into TH broth in order to enrich bacterial cells. The inoculated media were incubated at $37^{\circ} \mathrm{C}$ for 1-3 days. The bacteria found in each sample were identified and tested for antibiotic sensitivity by means of discs diffusion method according NCCLS. Six factors (Table 1) including species, patient's age, type of fracture, degree of soft tissue damage, presence of small bone fragments and the interval from the time of injury to the time of surgery were examined for the incidence of bone infection before internal fixation was performed.

Table 1

Criteria to evaluate the incidence of bacterial bone infection

\begin{tabular}{|c|c|c|c|c|}
\hline Data & \multicolumn{4}{|c|}{ Classification of criteria } \\
\hline Age of patients & \multicolumn{2}{|c|}{$<1$ year } & \multicolumn{2}{|c|}{$>1$ year } \\
\hline Type of surgical attire & \multicolumn{2}{|l|}{ Foliodrape $^{\circledR}$} & \multicolumn{2}{|c|}{ Cotton gown and Polydrape ${ }^{\circledR}$} \\
\hline \multirow[t]{2}{*}{ Type of fracture } & \multirow{2}{*}{\multicolumn{2}{|c|}{ Close }} & \multicolumn{2}{|c|}{ Open (Table 4.3) } \\
\hline & & & Type I & Type II Type III \\
\hline Soft tissue damage & Mild & \multicolumn{2}{|l|}{ Moderate } & Severe \\
\hline Fracture with bone fragment & \multicolumn{2}{|l|}{ Yes } & \multicolumn{2}{|l|}{ No } \\
\hline $\begin{array}{l}\text { Interval from the time of injury } \\
\text { to the time of surgery }\end{array}$ & 1-2 days & \multicolumn{2}{|l|}{ 3-4 days } & More than 5 days \\
\hline Radiographic abnormalities & Yes & \multicolumn{2}{|l|}{ No } & Unknown \\
\hline Type of internal fixation & Plates and screws & \multicolumn{2}{|c|}{ Kirchner pin } & $\begin{array}{l}\text { Screws combination } \\
\text { with pins }\end{array}$ \\
\hline Type of bone healing & \multicolumn{2}{|c|}{ Primary } & \multicolumn{2}{|c|}{ Secondary } \\
\hline Duration of anaesthesia & \multicolumn{2}{|c|}{ Less than 100 minutes } & \multicolumn{2}{|c|}{ More than 100 minutes } \\
\hline Method of anaesthesia & \multicolumn{2}{|c|}{ With propofol } & \multicolumn{2}{|c|}{ Without propofol } \\
\hline Bacterial culture & Negative & \multicolumn{2}{|c|}{ Indirect culture } & Direct culture \\
\hline
\end{tabular}

In the latter part, one gram of tissue and internal fixations were obtained from each of 41 patients when the internal fixations were removed. One gram of tissue at the fracture site was transferred into Amies transport medium (CM 425, Oxoid) and internal fixation devices were put into Cary-Blair medium (CM 519, Oxoid) as the transport medium. The bacterial cultivation was performed in the same procedure as in the first part. Eleven factors, including the age of patients, type of fracture, degree of soft tissue damage, presence of small bone fragments, interval from trauma to surgery, positive bacterial culture results before implantation, abnormal radiographic findings, type of internal fixations, type of bone healing, type of anaesthesia, and duration of anaesthesia when the osteosynthesis was performed were evaluated (Table 1).

Since $P$. aeruginosa strains were frequently isolated, we separately evaluated the incidence of $P$. aeruginosa infection in each group of patients in order to properly determine the incidence of bacterial bone infection. Cefazolin $(20 \mathrm{mg} / \mathrm{kg})$ was intravenously administered to all patients as soon as the sample was collected.

Statistical analysis

All criteria were analyzed by using $\chi^{2}$ test and Fischer's exact test with $p<0.05$ and $p<0.01$ to evaluate the incidence bone infection in each group of patients.

\section{Results}

\section{Aseptic techniques evaluations}

Surgical site preparation methods were theoretically supposed to be effective and appropriate to reduce a number of bacteria at the surgical site. Due to the efficacy of antiseptics used and methods of preoperative preparation of patients we assumed that it was sufficient to prevent the bacterial contamination of the surgical site.

\section{Incidence of fracture and infection}

The most frequently fractured bones were the tibia (43.33\% of long bone fractures), followed by the femur $(26.67 \%)$, the radius and ulna $(18.33 \%)$ and the humerus $(11.67 \%)$. 
Once each fracture was categorized by localization and type of fracture line, the diaphyseal complex (25.4\%), diaphyseal transverse (24.2\%), metaphyseal and/or physeal and/or epiphyseal extraarticular (16.7\%), intraarticular (16.8\%), and diaphyseal oblique or spiral $(16.9 \%)$ fractures were found. The positive bacterial findings were frequently detected in the patients with tibial $(69.23 \%)$ and radial $(63.63 \%)$ fractures.

\section{Type of surgical attire}

Two types of surgical attire were used in this study (96 operations) including non-woven disposable surgical gowns, drape, incise drape (Foliodrape ${ }^{\circledR}$ ) and reusable woven cotton surgical gowns with disposable non-woven polypropylene drape (Polydrape ${ }^{\circledR}$ ). The incidence of bacterial findings found between these types of surgical attire was significantly different $(p<0.05)$. The positive bacterial results were frequently found in 48 operations (70.58\%) performed with reusable surgical gown and non-woven disposable drape (Polydrape ${ }^{\circledR}$ ) whereas only a few bacterial findings were detected in the operations performed with Foliodrape ${ }^{\circledR}(3 / 28,10.7 \%)$. Once the types of surgical attire were statistically analyzed for their influences on the positive results among each group of patients categorized by several factors, which may influence the risk of infection, there was no statistical difference in the positive results between types of surgical attire and each factor.

\section{Bacterial culture before implantation}

The negative and positive results of bacterial culture were found in 21 patients $(38.18 \%)$ and in 34 patients $(61.81 \%)$, respectively. Among the patients with the isolation of bacteria, there was mixed bacterial infection in 6 patients $(17.64 \%)$ and single pure bacterial cultures in 28 patients $(82.35 \%)$. In all patients bacteria can be isolated via enrichment in broth media. Bacterial species found in the patients before were Pseudomonas aeruginosa (50.0\%), Staphylococcus epidermidis (20.6\%), Staphylococcus aureus (8.82\%), Staphylococcus intermedius (5.88\%), Bacillus spp. (5.88\%), Corynebacterium (5.88\%), Proteus mirabilis (5.88\%), Escherichia coli (5.88\%), Staphylococcus spp. (2.94\%) and Enterococci (2.94\%). The differences in detection of bacteria among species, patient's age, patient with or without small bone fragments, and patient with different durations from trauma to surgery were not statistically significant. On the other hand, statistical differences were found in the patients with different fracture types and those with different degrees of soft tissue damage. We found that patients with open fractures and those with severe degree of soft tissue damage had significantly higher positivity of bacterial culture $(p<0.01)$.

\section{Bacterial culture after metallic implantation}

The negative results of bacterial culture were found only in 8 patients $(19.51 \%)$ whereas the positive results were found in 33 patients $(80.48 \%)$ after implantation. The incidence of bacterial infection after implantation was significantly higher than that before implantation $(p<0.05)$. Among the patients with culture of bacteria, there was mixed bacterial infection in 5 patients $(15.15 \%)$ and single bacterial species in 28 patients $(84.84 \%)$. The incidences of mixed and single bacterial infection before and after implantation were not different. The bacteria could be isolated via primary cultivation on agar plate media in 4 patients $(9.76 \%)$. As a whole, bacteria found in the patients before and after implantations were almost in the same species or genus and incidences including Pseudomonas aeruginosa (51.51\%), Staphylococcus epidermidis (21.21\%), Staphylococcus intermedius (12.12\%), Staphylococcus haemolyticus (12.12\%), Staphylococcus aureus (3.03\%), Staphylococcus spp. (15.15\%), Bacillus spp. (6.06\%), Escherichia coli (3.03\%), and enterococci (3.03\%). The incidences of bacterial findings were not significantly different among each group of patients categorized by type of fracture, degree of soft tissue damage, presence of small bone 
fragments, the interval from trauma to surgery, and duration of anaesthesia. On the other hand, the patients of younger age (less than 1 year), those with plate and screws internal fixation, those with positive bacterial results before implantation, those with primary bone healing, those with abnormal radiographic findings, and those administered intramuscular anaesthesia had significantly higher positive bacterial culture results after implantation $(p<0.05)$.

In our investigation, we found that only 2 patients $(3.33 \%)$ had clinical problems after osteosynthesis. Both of them had positive bacterial results before and after implantation and also had radiographic abnormalities (bone lysis around implants, periosteal reaction, and loose implants).

\section{Discussion}

In our study, incidence rate of type and localization of long bone fractures were the same as in the previous report (Dvořák et al. 2000). We found the tibia and fibula (43.33\%) and the femur $(26.67 \%)$ to be the most frequently fractured bones whereas the previous report (Dvořák et al. 2000) showed that the radius and ulna were the most commonly fractured. However, our number of patients is lower than that reported in the previous study. In addition, our study excluded the patients with previous antibiotic treatment. Furthermore, we also found similar to the previous reports that the incidence of bone infection is high in tibia and radius fractures. Due to less dense muscle covering the bone at these sites, it was found that infection always occurred in the tibia and the radius (Braden 1991; B raden et al. 1989; Carek et al. 2001; Caywood 1983; Fitzgerald et al. 1992; Johnson 1994).

Because the surgical site infection etiology is multi-factorial, the sterilization, preoperative patient preparation and operating theatre environments must be considered as the main sources of this bacterial contamination. Antiseptics used in our practice were theoretically supposed to be effective. Since povidone-iodine and chlorhexidine have a broad spectrum of antimicrobial activity against vegetative bacteria, fungi, viruses, protozoa, and yeasts, they are suitable for removing bacteria from the skin surface at preoperative surgical site (Lemarie and Hos good 1995). Additionally, povidone-iodine surgical scrub is also used extensively in veterinary practice for the pre-operative preparation of patients and surgeons (Amber et al. 1983).

Surgical attire used in the operation also plays an important role in the sterilization in the operation theatre and postoperative wound infection. We found that Foliodrape ${ }^{\circledR}$ was mainly selected in the osteosynthetic procedures (when internal fixations were performed) whereas reusable gown and non-woven drape were always used when the implants were removed. Due to the high cost of Foliodrape ${ }^{\circledR}$, it is always selected when osteosynthesis is performed or when the risk of infection is high. According to our results, the positive bacterial results from the osteosynthetic procedures (before implantation) seem to be lower than those when the implants are removed. These types of surgical attire may interfere with the positive bacterial results before and after implantation. However, we did not find any statistical differences of positive culture results between each factor and surgical attire. Our results showed that the disposable non-woven surgical gowns, drape, and incision drape (Foliodrape ${ }^{\circledR}$ ) could effectively reduce the bacterial contamination of the surgical wound. We suggested that Foliodrape ${ }^{\circledR}$ should be used in the operations which have high risk of infection, such as joint prosthesis, and when large metallic internal fixations are performed. The woven surgical gown and Polydrape ${ }^{\circledR}$ can be used in soft tissue surgery, or in routine orthopaedic procedures which have lower risk of infection.

The microbiological cultivation methods used in our present study were supposed to be effective in identifying aerobic bacteria (A biag om and v an Horn 2002). Amies and Carry Blair transport mediums were used as transport mediums in our study. Both are acceptable 
as effective transport mediums that can prolong the survival of both aerobic and anaerobic bacteria such as Staphylococcus, Pseudomonas, E. coli, Enterococcus, Peptostreptococcus, Prevotella, Streptococcus, Haemophilus, Neisseria, Fusobacterium etc. (Abiagom and van Horn 2002; Colasante et al. 2002; Ferrington and Brown 2002; Robinson and Gruver 2002; Sarina and Knoll 2002). Bacterial cultivation was performed by inoculation samples onto the blood agar medium and MacConkey's agar (solid media). The enrichment in broth media was used to detect only few bacterial cells in the sample. The types of bacterial species found in our study were in agreement with the other previous reports (Braden 1991; Braden et al. 1989; Calza et al. 2001; Carenti-Etesse et al. 1999; Caywood 1983; Caywood et al. 1978; Costerton and Marrie 1985; Fitzgerald 1983; Fitzgerald et al. 1992; Griffiths and Bellenger 1979; Harrari 1984; Johnson 1994; Lew and Waldvogel 1997; Smith et al. 1978). Since $P$. aeruginosa was frequently found in our study, we assumed that it was the main nosocomial pathogen in our operating theatre. Furthermore, this species was also classified as the main nosocomial pathogen in humans (Stein et al. 1998; Lobati et al. 2001; Valenziano et al. 2002). The mixed bacteria identified from the samples before and after implantation were in the same incidence. However, in the present study, multimicrobial bone infections were commonly found in the patients with open fractures and always contained mixtures of staphylococci as well as gram-negative aerobic rods such as Escherichia coli, Pseudomonas spp., Proteus spp. and Klebsiella spp. (Hirsch and Smith 1978). Bacteria commonly found in primary wound cultures in open fractures in extremities were Staphylococcus species (Popovitch and Nannos 2000; Shuttlew orth et al. 1997) such as S. epidermis, S. aureus (Calza et al. 2001) and also Pseudomonas aeruginosa (Carsenti-Etesse et al. 1999, Greenberg et al. 2000, Calza et al. 2001, Shirliff et al. 2002).

Since the collecting, transporting, and cultivation methods for anaerobic bacterial evaluation are difficult and complicated, our present study was not performed for anaerobic bacterial identification. Furthermore, osteomyelitis caused by anaerobic bacteria always shows typical signs, such as a foul odor and the presence of sequestra (John s on et al. 1984; Walker et al. 1983) and it is rarely identified in the osteosynthetic procedures. Thus, it was excluded from our study, which focused only on aerobic bacteria, which tend to play more important role in orthopaedic procedures. However, there seems to have been more interest in recent decades in anaerobic bacteria, which can cause osteomyelitis including Peptostreptococcus anaerobius, Propionibacterium spp., Actinomyces viscosus, Fusobacterium nucleatum, and Bacteroides spp. (Muir and John son 1992; Hodg in et al. 1992; Walker et al. 1983). Therefore, further studies should be performed to identify the type and incidence of anaerobic bacteria when osteomyelitis, whose cause is unknown, occurs in clinical practice.

According to our results, it was shown that the young patients (less than 1 year of age) were at higher risk of bacterial infection after osteosynthesis. Due to immature host defense, they are susceptible to bacterial infection especially when the large metallic implants such as bone plates and screws are in place. These may cause a severe degree soft tissue damage. To our knowledge, there is no veterinary report available concerning the incidence of posttraumatic bone infection in young and old patients. It was mentioned that posttraumatic osteomyelitis is not an age-specific disease (B raden 1991; Cay w ood 1983). However, for posttraumatic osteomyelitis there appears to be a slight predilection in young male animals due to the increased incidence of trauma in this subset (Braden 1991; Caywood et al. 1978; Radas ch 1993; Nečas et al. 2002a; B aran yiová et al. 2002, 2003). Furthermore, the patients with intramuscular anaesthesia also had high risk of bacterial infection. Due to our anaesthetic protocols in young patients, intramuscular anaesthesia (medetomidine in combination with ketamine) was mainly performed in the patients of young age. Thus the 
positive results in this group of patients were also high, even though the intramuscular anaesthesia might not influence the incidence of infection.

As a whole, the patients with open fractures tended to have a higher risk of bone infection than those with closed fractures. Incidence of osteomyelitis following open fractures is reported to be $2-16 \%$ depending significantly on the grade of trauma and the type of treatment administered (Kaim et al. 2001). In open fractures, bacteria can easily enter into the bone even by open wound or by the surgical approach when performing osteosynthesis. Additionally, an association with severe soft tissue damage in these patients puts them at a higher risk of infection (Carenti-Etesse et al. 1999; Lew and Waldvogel 1997; Petty et al. 1985). In accordance with these data, we also found that these patients had a higher risk of infection. Bacteria found in patients with open fracture include P. aeruginosa, Staphylococcus aureus, and Staphylococcus epidermidis. Furthermore, according to our investigation, $P$. aeruginos $a$ was frequently found in the sample of the patients with closed fractures before and after implantation whereas the other bacteria (staphylococci, enterococci, E. coli) were mainly found in patients with open fractures. Thus, it was concluded that $P$. aeruginosa might be the main nosocomial pathogen in our operating theatre.

Other factors, which can promote cryptic infection of the bone, are the degree of soft tissue damage, type of internal fixation, and interval from the time of injury to the time of treatment, avascular bone fragment, and duration of surgery (Petty et al. 1985). Soft tissue trauma and fracture fixation using metallic implants may produce structural and functional damage to the local host tissue causing devascularization, malperfusion, disturbance of endothelial permeability, hypoxia, acidosis, haematoma, edema, and increased intracompartmental pressure (Gristina et al. 1991; Wichmann et al. 1996). This may result in an impaired humoral and cellular immune competence (Hock et al. 1993). On a local level it may decrease resistance to the pathogenic microbiological load with subsequent manifestation of infection in the traumatized tissue (B alto et al. 2001; Hoch et al. 1993; Nair et al. 1996; Petty et al. 1985). Nevertheless, numerous clinical investigations have shown that operative treatment of closed fractures with severe soft tissue injury is associated with a higher risk of infection than that without severe soft tissue injury (Kalicke et al. 2003; Siebert et al. 1995). These investigations indicate that even without major bacterial contamination, soft tissue damage and its pathophysiological consequences act as a catalyst for infection since they reduce resistance to infection.

Fracture stabilization with metallic implants, such as plates and screws, require tissue trauma and devitalization during implantation, provide a relatively large surface area for bacteria with adherent properties, and provide a mechanical barrier to the immune system. Alteration of cellular activity associated with prolonged fracture healing and a small amount of bacteria in a cryptic infection may cause osteomyelitis. Although cryptic infection itself may not cause any clinical problems, whenever the host defense mechanisms are suppressed (i.e. systemic diseases, hypersensitivity to metallic implants), the bacteria may be recalcitrant and cause the infection leading to implant failure (Lob ati et al. 2001). In our study, we found that the patients with internal fixations with plates and screws were at a higher risk of infection. Due to more severe tissue damage, longer surgery, and large metallic implants, cryptic infection easily occurred when the plate and screws fixation were performed. However, we did not find any statistical difference of bacterial culture results among patients that underwent different durations of operation. Thus the invasive surgical techniques, intensive sterile techniques, and antimicrobial prophylaxis selection for the orthopaedic procedure play important roles in prevention of bone infection as well (Parker 1987).

The interval from the time of injury to the time of treatment also plays an important role 
especially in patients with open fracture. Bacteria entering into the fractured bone can multiply in the necrotic tissues and haematoma (Hoch et al. 1993; Petty et al. 1985). However, we did not find any statistical differences among patients with different intervals. The bacterial culture results in the patients with long interval may be influenced by antibiotic administered to stabilize the systemic condition before surgery. Moreover, we also found that the patients with primary bone healing had higher positive bacterial culture results than those with secondary bone healing. Due to compression force between bone fragments performed to achieve the primary bone healing, this force may create the necrosis of bone. Thus the patients in this group seem to have a higher risk of infection. It can explain that the high risk of infection due to plate and screw fixation may contribute to infection (Cordero et al. 1994). Additionally, the compression dynamic plate (DCP) will increase the stress at the fracture site and it may produce bone necrosis. Because of lack of blood vessel supply at the fracture site, the cryptic infection may easily become manifest (Arens et al. 1996).

We also found that the positive bacterial culture results before implantation and abnormal radiographic findings were related to the positive bacterial culture results after implantation. The patients who had the positive results before implantation also had a higher risk of infection after implantation. The same groups or species of bacteria found before and after implantation were found in more than $70 \%$ of patients with positive results. Radiographic abnormalities such as bone lysis and/or periosteal reaction were found in 11 patients who had positive results both before and after implantation. Two of them also had clinical problems including delayed bone healing, loose implants, and osteomyelitis. Thus we concluded that positive bacterial culture results before implantation and radiographic abnormalities can predict the risk of bone infection when osteosynthetic procedures are performed.

Given that the overall infection rate for clean, elective surgical procedures in the present study was in line with values reported for human patients (Stevenson et al. 1986), it is unlikely that an abnormally high bacterial burden was a problem in our hospital. Operating room protocols and surgical sterility appeared to be adequate. However, compared with previous reports, the high percentage of Pseudomonas aeruginosa isolates was an unusual finding. Therefore, a change may be warranted in the choice of antimicrobials used in our hospital in patients in which infections are suspected but results of bacterial culture and susceptibility testing are not yet known. Knowledge of the commonly isolated organisms and their antimicrobial susceptibility patterns within a given hospital assists in the selection of appropriate antimicrobial treatment. In most patients with cephalosporins given prophylactically, the antimicrobial was not effective against Pseudomonas spp. as reported by (Edin et al. 1996). Therefore, we cannot comment on what value appropriate prophylactic antimicrobial treatment might have provided. Our findings do, however, give weight to the efforts to reduce the prophylactic use of antimicrobials in our hospital and emphasize the importance of hospital-specific epidemiologic studies of infection rates (Shirtliff et al. 2002; Stein et al. 1998). According to our results, it is recommended to administer the first generation of cephalosporins during preoperative operation in every patient (Edin et al. 1996; Love and Johnson 1992; Patel et al. 2000; Whittem et al. 1999). In patients with a high risk of infection, such as polytraumatized or immunosuppressed individuals, the patients who have undergone prosthetic joint or large metallic implants, the quinolone group such as enrofloxacin should be added and postoperative care should be performed intensively to prevent posttraumatic osteomyelitis (Greenberg et al. 2000). 


\section{Posttraumatická bakteriální infekce kostí končetin malých zvířat před a po osteosyntéze}

Posttraumatická infekce kostí (osteomyelitis) je jednou z nejzávažnějších komplikací osteosyntézy. Při ortopedických operacích je proto indikováno profylaktické podání antibiotik (chráněné koagulum v průběhu operace), přičemž antibiotiky první volby jsou v těchto případech cefalosporiny první generace. Tyto preparáty však nezaručují eradikaci všech bakterií, které pak v průběhu chirurgického zákroku mohou proniknout do místa lomu.

Cílem této studie bylo určit nejčastější bakteriální agens vykultivovaná ze stěrů získaných během osteosyntézy, aby mohla být zvolena nejvhodnější antibiotická profylaxe pro naši klinickou praxi. Do studie bylo zařazeno 60 pacientů s frakturami dlouhých kostí končetin ošetřenými osteosyntézou na Oddělení chirurgie a ortopedie Kliniky chorob malých zvířat Veterinární a farmaceutické univerzity Brno. U pacientů zařazených do studie nebyla $\mathrm{v}$ období minimálně 24 hodin před operací podána žádná antibiotika. Stěry pro mikrobiální kultivaci byly odebrány před a po přiložení implantátů $\mathrm{k}$ vnitřní fixaci zlomeniny. Byly hodnoceny některé rizikové faktory rozvoje infekce. Vyšší riziko vzniku infekce před operací bylo zjištěno u pacientů $\mathrm{s}$ rozsáhlým poškozením měkkých tkání a $\mathrm{v}$ případech otevřených zlomenin. Naopak vyšší riziko rozvoje infekce po provedené osteosyntéze bylo zjištěno u pacientů mladších jednoho roku, u pacientů s pozitivní bakteriální kultivací před operací, u pacientů, u nichž byla použita ploténka se šrouby, u pacientů s primárním hojením kostí, s rentgenologickými abnormalitami hojení zlomeniny a u pacientů v intramuskulární anestezii. Vysoké procento bakteriálních izolátů v naší studii představovala Pseudomonas aeruginosa rezistentní na cefalosporiny. Ačkoli na naší klinice jsou u všech pacientů před operací používány právě cefalosporiny, incidence pooperačních infekcí byla velmi nízká. Z našich výsledkủ je tedy patrné, že za normálních okolností je dostačující běžná předoperační profylaktická aplikace antibiotik. V případech zvýšeného rizika rozvoje infekce (polytraumatický nebo imunosuprimovaný pacient, použitî endoprotézy nebo velkých kovových implantátů), nebo tam, kde se již infekce rozvinula, je důležitá znalost specifické epidemiologické situace na daném pracovišti a následné použití antibiotik účinných proti aktuálním patogenům. V našich podmínkách u těchto př́ípadů doplňujeme cefalosporiny první generace použitím chinolonů (enrofloxacin) a zvýšenou pooperační péčí, abychom předcházeli rozvoji posttraumatické osteomyelitidy.

\section{Acknowledgement}

The authors would like to thank Dr. Srnec and Dr. Novotná from Small Animal Clinic, FVL FVU Brno for assistance with animal operations and care, and Dr. Jahnová from the Department of Microbiology and Immunology, FVL VFU Brno for technical assistance with the bacterial cultivation.

This work was supported by the Ministry of Education, Youth and Sports of the Czech Republic (Research Project No. 161700002).

\section{References}

ABIAGOM, T, VAN HORN, K 2002: New direct quantitative method for comparative evaluation of swab collection and transport systems. ASM $102^{\text {nd }}$ General meeting, Salt Lake City, Utah. Poster session. 57/C: C72

ALLIGNET, J, GALDBART, JO, MORVAN, A, DYKE, KGH, VAUDAUX, P, AUBERT, S, DESPLACES, N, EL SOLH, N 1999: Tracking adhersion factors in Staphylococcus caprae strains responsible for human bone infection following implantation of orthopaedic material. Microbiol 145: 2033-2042

AMBER, EI, HENDERSON, RA, SWAIM, SF 1983: A comparison of antimicrobial efficacy and tissue reaction of four antiseptics on canine wounds. Vet Surg 12: 63-68

ARENS, ST, HANSIS, M, SCHLEGEL, U, EIJER, H, PRINTZEN, G, ZIEGLER, WJ, PERREN, SM 1996 Infection after open reduction and internal fixation with dynamic compression plates- Clinical and experiment data. Injury 27, Suppl. 3: 27-33

BALTO, K, SASAKI, H, STASHENKO, P 2001: Interleukin-6 deficiency increases inflammatory bone destruction. Infect Immun 69: 744-750 
BARANYIOVÁ, E, HOLUB, A, MARTINÍKOVÁ, M, NEČAS, A, ZATLOUKAL, J 2002: Intraspecies aggression and bite wounds in dogs. Proceedings of the 36th International Congress of the ISAE, August 6-10. Ed. P Koene, Wageningen, The Netherlands, p. 171

BARANYIOVÁ, E, HOLUB, A, MARTINÍKOVÁ, M, NEČAS, A, ZATLOUKAL, J 2003: Epidemiology of intraspecies bite wounds in dogs in the Czech Republic. Acta Vet Brno 72: 55-62

BRADEN, TD 1991: Posttraumatic osteomyelitis. Vet Clin North Am Small Anim Pract 21: 781-811

BRADEN, TD, TVEDTEN, HW, MOTOSKY, UV 1989: The sensitivity and specificity of radiology and histopathology in the diagnosis of post-traumatic osteomyelitis. Vet Comp Orthop Traumatol 3: 98-103

CALZA, L, MANFREDI, R, BRIGANTI, E, ATTARD, L, CHIODO, F 2001: Iliac osteomyelitis and gluteal muscle abscess caused by Streptococcus intermedius. J Med Microbiol 50: 480-482

CAREK, PJ, DICKERSON, LM, PHARM, D, SACK, JL 2001: Diagnosis and Management of Osteomyelitis. Am Fam Physician 63: 2413-2420

CARSENTI-ETESSE, H, DOYON, F, DESPLACES, N, GAGEY, O, TANCREDE, C, PRDIER, C, DUNAIS, B, DELLAMONICA, P 1999: Epidermiology of Bacterial infection During Management of Open Leg Fractures. Eur J Clin Infect Dis 18: 315-323

CAYWOOD, DD 1983: Osteomyelitis. Vet Clin North Am Small Anim Pract 13: 43-53

CAYWOOD, DD, WALLACE, LJ, BRADEN, TD 1978: Osteomyelitis in the dogs: A review of 67 cases. J Am Vet Med Assoc 172: $943-946$

COLASANTE, GG, INGALSBE, B, JACOB, N, BERGER, C 2002: Comparison of Starpex Star Swab with a new fisherbrand Amies agar gel transport swab for the recovery of fastidious aerobic and anaerobic bacteria. ASM $102^{\text {nd }}$ General meeting, Salt Lake City, Utah. Poster session 57/C:C76.

CORDERO, J, MUNUERA, L, FOLGUEIRA, MD 1994: Influence of metal implants on infection. J Bone Joint Surg 26: $1-56$

COSTERTON, JW, MARRIE, TJ 1985: Mode of growth of bacterial pathogens in chronic polymicrobial human osteomyelitis. J Clin Microbiol 22: 924-932

DVOŘ́K, M, NEČAS, A, ZATLOUKAL, J 2000: Complications of long bone fracture healing in dogs: functional and radiological criteria for their assessment. Acta Vet Brno 69:107-114

EDIN, ML, MICLAU, T, LESTER, GE 1996: Effect of cephazolin and vancomicin on osteomyelitis in vitro. Clin Orthop 333: 245-251

FERRINGTON, M, BROWN, DFJ 2002: Comparison of five swab systems for the transport of pathogenic bacteria: effects of charcoal in the swab or gel medium. ASM $102^{\text {nd }}$ General meeting, Salt Lake City, Utah. Poster session 57C:C70

FITZGERALD, RH 1983: Experimental osteomyelitis: Description of a canine model and role of depot administration of antibiotics in the prevention and treatment of sepsis. J Bone Joint Surg Am 65: 371-380

FITZGERALD, RH, WHALEN, JL, PETERSON, SA 1992: Pathophysiology of osteomyelitis and pharmacokinetics of antimicrobial agents in normal and osteomyelitic bone. In : ESTERHAI JL, GRISTINA AG, POSS R, Eds. Musculoskeletal infection. Park Ridge, III American Academy of Orthopaedic Surgeons, pp. 387-399

GREENBERG, RN, NEWMAN, MT, SHARIATY, S, PECTOL, RW 2000: Ciprofloxacin, Lomefloxacin, or Levofloxacin as Treatment for Chronic Osteomyelitis. Antimicrob Agents Chemother 44: 164-166

GRIFFITHS, GL, BELLENGER, CR 1979: A retrospective study of osteomyelitis in dogs and cats. Aust Vet J 55 : $587-591$

GRISTINA, G, COSTERTON, JW 1989: Bacterial adherence and glycocalyx and their role in musculoskeletal infection. J AmVet Med Assoc 195: 765-767

GRISTINA, AG, NAYLOR, PT, MYRVIK, QN 1991: Mechanisms of musculoskeletal sepsis. Orthop Clin North Am 22: 363-371

HARRARI, J 1984: Osteomyelitis. J Am Vet Med Assoc 184: 101-102

HIRSCH, DC, SMITH, TM 1978: Osteomyelitis in the dog: Microorganisms isolated and susceptibility to antimicrobial agents. J Small Anim Pract 19: 679-687

HOCH, RC, RODRIGUEZ, R, MANNING, T, BISHOP, M, MEAD, P, SHOEMAKER, WC 1993: Effects of accidental trauma on cytokine and endotoxin production. Crit Care Med 21: 839-845

HODGIN, EC, MICHAELSON, F, HOWERTH, EW, AUSTIN, F, DAVIS, F, HAASE, AS 1992: Anaerobic Bacterial Infections causing osteomyelitis/arthritis in a dog. J AmVet Med Assoc 201: 886-888

JOHNSON, KA 1994: Osteomyelitis in dogs and cats. J AmVet Med Assoc 205:1882-1887

JOHNSON, KA, LOMAS, GR, WOOD, AKW 1984: Osteomyelitis in dogs and cats caused by anaerobic bacteria. Aust Vet J 61: 57-61

KAIM, AH, GROSS, T, SCHULTHESS, GKV 2001: Imaging of chronic posttraumatic osteomyelitis. European Radiology 2001 published online internet.

KALICKE, T, SCHLEGEL, U, PRINTZEN, G, SCHNEIDER, E, MUHR, G, ARENS, S 2003: Influence of a standardized closed soft tissue trauma on resistance to local infection. An experimental study in rats. J Orthop Res 21: 373-378

LEMARIE, RJ, HOSGOOD, G 1995: Antiseptics and Disinfectants in Small Animal Practice. Comp Cont Ed Vet Pract 17: 1339-1349 
LEW, DP, WALDVOGEL, FA 1997: Osteomyelitis. N Eng J Med, 336: 999-1007

LOBATI, F, HERNDON, B, BAMBERGER, D 2001: Osteomyelitis: Etiology, Diagnosis, Treatment and Outcome in a Public versus as Private Institution. Infection 6: 333-336

LOVE, DN, JOHNSON, KA 1992: Antimicrobial sensitivity of staphylococci isolated from dogs. Aust Vet Pract 19: $196-200$

MARCELLIN-LITTLE, DJ, SELLON, RK, KYLES, AE, LEMONS, CL, KAUFMAN, L 1996: Chronic localized osteomyelitis caused by typical infection with Blastomyces dermatitis in a dog. J Am Vet Med Assoc 209: 18771879

MILLER, CW, SUMNER-SMITH, G, SHERIDAN, C, PENNOCK, PW 1998: Using the Unger system to classify 386 long bone fractures in dogs. J Sm Anim Pract 39: 390-393

MUIR, P, JOHNSON, KA 1992: Anaerobic bacteria isolated from osteomyelitis in dogs and cats. Vet Surg 21: 463-466

NAIR, SP, MEGHJI, S, WILSON, M, REDDI, KA, WHITE, P, HENDERSON, B 1996: Bacterially induced bone destruction: mechanisms and misconceptions. Infect Immun 64: 2371-2380

NEČAS, A, BARANYIOVÁ, E, HOLUB, A, MARTINÍKOVÁ, M, ZATLOUKAL, J 2000a: Pokousání při střetech psů. Program a abstrakty 27. etologiké konference ČSETS, Brno - Nové Dvory, 4.-6. května, p. 38

NEČAS, A, MEZEROVÁ, J, RAUŚER, P 2000b: Obecná chirurgie a anesteziologie. In : SVOBODA, M, SENIOR, DF, DOUBEK, J, KLIMES, J: Nemoci psa a kočky. I. díl, Noviko a.s., pp. 193-237

PARKER, RB 1987: Treatment of Post-traumatic Osteomyelitis. Vet Clin North Am Small Anim Pract 17: 841856

PATEL, R, PIPER, KE, ROUSE, MS, STECKELBER, G 2000: Linezolid Therapy of Staphylococcus aureus Experimental Osteomyelitis. Antimicrob Agents Chemother 44: 3438-3440

PETTY, W, SPANIER, S, SHUSTER, JJ 1985: The influence of skeletal implants on the incidence of infection. J Bone Joint Surg Am 67: 1236-1244

PLIERMATTEI, DL, FLO, GL 1997: Small animal orthopaedics and fracture repair ( $3^{\text {rd }}$ ed.), WB Saunders, $744 \mathrm{p}$.

POPOVITCH, CA, NANNOS, AJ 2000: Emergency management of open fracture and Luxations. Vet Clin North Am Small Anim Pract 30: 645-656

RADASCH, RM1993: Osteomyelitis. In Harari J (Ed): Surgical Complication and Wound Healing. Philadelphia, WB Saunders, pp. 223-254

ROBINSON, A, GRUVER, ML 2002: Comparison of bacterial survival in two transport systems stored at room and refrigerator temperatures. ASM $102^{\text {nd }}$ General Meeting, Salt Lake City, Utah. Poster Session: C69

SALTER, RB, HARRIS, WR 1963: Injuries involving the epiphyseal plate. J Bone Joint Surg 45A: 587-592

SARINA, M, KNOLL, B 2002: Comparative study of an Amies transport system incorporating new easy-flow swab applicators, designed for improved sample release, with a transport system utilizing regular rayon swabsStarswab II, using a direct swabbing technique. ASM $102^{\text {nd }}$ General meeting, Salt Lake City, Utah. Poster session 57/C:C-68

SHIRLIFF, ME, CALHOUN, JH, MADER, JT 2002: Gatifloxacin Efficacy in Treatment of Experimental Methicillin-Sensitive Staphylococcus aureus-Induced Osteomyelitis in Rabbits. Antimicrob Agents Chemother 46: $231-233$

SHUTTLEWORTH, R, BEHME, RJ, McNABB, A, COLBY, WD 1997: Human Isolates of Staphylococcus caprae: association with bone and joint infection. J Clin Microbiol 35: 2537-2541

SIEBERT, CH, ARENS, S, HANSIS, M 1995: The role of surgical trauma in the aetiology of postoperative wound infection-quantification of surgery induced trauma. Hyg Med 20: 474-480

SMEAK, DP, OMSTEAD, ML, HOHN, RB 1987: Brucella canis osteomyelitis in two dogs with total hip replacement. J Am Vet Med Assoc 191: 986-989

SMITH, CW, SCHILLER, AG, SMITH, AR 1978: Osteomyelitis in the dog: A retrospective study. J Am Anim Hosp Assoc 14: 589-592

STEIN, A, BATAILlE, JF, DRANCOURT, M, CURVALE, G, ARGENSON, JN, GROULIER, P, RAOULT, D 1998: Ambulatory treatment of multidrug-resistant Staphylococcus infected orthopaedic implants with high-dose oral co-trimazole (Trimethoprim-Sulfamethoxazole). Antimicrob Agents Chemother 42: 3086-3091

STEVENSON, S, OMSTEAD, ML, KOWALSKI, J 1986: Bacterial culturing for prediction of postoperative complication following open fracture repair in small animals. Vet Surg 15: 99-102

SWERCZEK, TW, DONAHUE, JM, HUNT, RJ 2001: Scedosporium prolificans infection associated with arthritis and osteomyelitis in horse. J AmVet Med Assoc 218:1800-1802

VALENZIANO, CP, CHATTER-CORA, D, O’NEILL, A, HUBLI, EH, CUDJOE, EA 2002: Efficacy of primary wound cultures in long bone open extremity fractures: are they of any value? Arch Orthop Trauma Surg 122: 259-261

WALDVOGEL, FA, VASEY, H 1983: Osteomyelitis: The past decade. N Eng J Med 303: 360-372

WALKER, RD, RICHARDSON, DC, BRYANT, MJ 1983: Anaerobic bacteria associated with osteomyelitis in domestic animals. J Am Vet Med Assoc 182: 814-816 
WHITTEM, TL, JOHNSON, AL, SMITH, CW, SCHAEFFER, DJ, COOLMAN, BR, AVERILL, SM, COOPER, TK, MERKIN, GR 1999: Effect of perioperative prophylactic antimicrobial treatment in dogs undergoing elective orthopaedic surgery. J Am Vet Med Assoc 215: 212-216

WICHMANN, MW, ZELLWEGER, R, DEMASO, CM, AYALA, A, CHAUDRY, IH 1996: Enhanced immune responses in females as opposed to decreased responses in males following hemorrhagic shock. Cytokine $\mathbf{8}$ : 853-863 